\title{
ANALISIS TITIK RAWAN KECELAKAAN DI JALAN KERTANEGARA KABUPATEN MALANG
}

\author{
Rifky Aldila Primasworo ${ }^{*}$, Andy Kristafi Arifianto ${ }^{1)}$ \\ 1) Program Studi Teknik Sipil FT UNITRI, Jl. Tlaga Warna, Malang
}

\begin{abstract}
Kertanegara is one of the roads in Malang Regency. The location of Kartanegara Road is considered to be one of the locations prone to accidents due to the lack of traffic infrastructures such as signs and road markings. The road is also an alternative highway that connects Malang Regency to Batu City. The data obtained shows that traffic accidents amounted to 43 of all types of traffic violations from 2016-2018. In 2016, 2017, and 2018, the number of accident victims was 18 accidents, 9 accidents, and 16 accidents. The purpose of this study is to determine the characteristics of Kertanegara road, accident-prone points, and solutions used to reduce the number of accidents. The analytical method used is the analysis of road characteristics, Z-Score, and Cusum analysis. The results obtained that service level of Kertanegara road is 0.61 where the flow is stable, the traffic density is moderate. Based on the analysis of the determination of accident-prone points, the result of Kartanegara road segment, Malang Regency, has a Z-Score for segment I of 0.25 and segment II of 0.17 which is included in the accident-prone criteria because it has a positive ZScore. Kartanegara Road has also been identified as a black spot because it has a positive cusum value, including the Cusum segment I values of 7.00 and segment II of 13.3. The solution is to provide a traffic sign in the form of a traffic light at the intersection of Police Karangploso road and the intersection of Sentana road, providing management officer traffic flow in Simpang Nuril road and providing warning signs that are prone to accidents and vehicle speed limit at the Crossroads Kauman I and intersection Nuril road.
\end{abstract}

Key Words: accident prone point, black spot, Kertanegara road, road characteristics.

\section{PENDAHULUAN}

Kecelakaan lalu lintas merupakan peristiwa di mana kendaraan mengalami tabrakan dengan benda lain atau dengan sesama kendaraan sehingga mengakibatkan kerusakan. Kecelakaan lalu lintas dapat mengakibatkan luka-luka, kerugian material atau bahkan kematian. Menurut WHO, kecelakaan lalu lintas menelan 1,2 juta korban jiwa setiap tahunnya (Mubina, U. H., Gaus, A., Pasri, A. A., \& Damayanti, Y., 2020).

Kecelakaan adalah terjadinya proses atau peristiwa tidak terduga atau tidak sengaja antara kendaraan satu dengan lainnya yang menimbulkan kerugian dan korban jiwa (UU No. 22 Tahun 2009 tentang Lalu Lintas dan Angkutan Jalan, 2009). Berbagai faktor menjadi penyebab terjadinya kecelakaan lalu lintas, faktor pertama adalah manusia, yang kedua adalah kendaraan dan ketiga adalah faktor jalan. Ketiga faktor tersebut merupakan faktor umum yang sering menimbulkan terjadinya kecelakaan lalu lintas

Jalan merupakan prasarana transportasi darat, yang mencakup semua bagian jalan, bangunan pelengkap, dan perlengkapan lalu lintas, baik pada permukaan tanah, di atas dan/atau di bawah permukaan tanah, serta di atas dan/atau di bawah permukaan air, kecuali jalan kereta api dan jalan kabel (UU No. 38 tahun 2004 tentang Jalan, 2004)

Jalan Kartanegara merupakan jalan raya alternatif yang menghubungkan Kabupaten Malang menuju Kota Batu. Salah satu area titik rawan kecelakaan yang ada di daerah Karangploso Malang yaitu berada di Jalan Kartanegara. Lokasi Jalan tersebut dianggap sebagai salah satu lokasi titik rawan kecelakaan dikarenakan masih kurangnya sarana lalulintas seperti rambu lalulintas dan marka jalan. Berdasarkan data yang diperoleh diketahui bahwa kecelakan lalulintas berjumlah 43 dari semua jenis pelanggaran lalu lintas dari tahun 2016-2018. Pada tahun 2016 jumlah korban kecelakaan berjumlah 18 kecelakaan, tahun 2017 jumlah korban kecelakaan berjumlah 9 kecelakaan dan tahun 2018 korban kecelakaan berjumlah 16 kecelakaan (Data Satlantas Malang 2018). Aspek keselamatan lalu lintas dan angkutan jalan, meliputi: kendaraan bermotor umum, prasarana lalu lintas dan angkutan jalan, sumber daya manusia di bidang lalu lintas dan angkutan jalan, operasional dan lingkungan (Peraturan Menteri Perhubungan Republik Indonesia Nomor: PM 26 Tahun 2015 Tentang Standar Keselamatan Lalu Lintas Dan Angkutan Jalan, 2015) 


\section{Lokasi Rawan Kecelakaan Lalu Lintas}

Lokasi rawan kecelakaan lalu lintas ditentukan berdasarkan kriteria dalam (Peraturan Direktur Jenderal Perhubungan Darat Nomor: SK.2574/AJ.403/DRJD/2017, 2017):

1) Black-spot. Lokasi yang frekuensi kecelakaan lalu lintas dengan korban mati, atau kriteria lainnya melebihi standar tertentu dalam satu tahun.

2) Black-link. Panjang jalan yang mengalami tingkat kecelakaan/kematian/kriteria lain per kilometer, lebih besar daripada standar yang ditentukan dalam waktu satu tahun.

3) Black-area, adalah wilayah jalan yang mengalami frekuensi kecelakaan/kematian/ kriteria lain, lebih besar daripada standar yang ditentukan dalam waktu satu tahun.

4) Mass Treatment/Black Item. Bentuk individual jalan/tepi jalan, signifikan jumlahnya pada total jaringan jalan, dan (secara kumulatif) terlibat dalam banyak kecelakaan/kematian/kriteria lain, melebihi standar tertentu dalam satu tahun.

\section{Identifikasi Lokasi Kecelakaan Berdasarkan Frekuensi Kecelakaan}

\section{1) Z-Score}

Bilangan $\mathrm{z}$ dicari dari sampel yang berukuran $\mathrm{n}$, data $\left(X_{1}, X_{2}, X_{3}, \ldots ., X_{n}\right)$, dengan rerata pada simpangan baku $S$. Sehingga, dibentuk data baru $\left(Z_{1}\right.$, $\left.Z_{2}, Z_{3}, \ldots ., Z_{n}\right)$, dengan rerata $=0$ dan simpangan baku $=1$. Nilai $Z$, adalah:

$$
\mathrm{Zi}=\frac{X i-\ddot{X}}{S d}
$$

Keterangan:

$\mathrm{Z}_{\mathrm{i}}=$ Nilai Z-Score kecelakaan pada lokasi $i$

$\mathrm{S}_{\mathrm{d}}=$ Simpangan baku

$X_{i}=$ Jumlah data pada lokasi $i$

$\ddot{X}=$ Rerata

$i=1,2,3 \ldots ., \mathrm{n}$

Klasifikasi penentuan daerah rawan kecelakaan (blacksite) ditunjukkan pada Tabel 1.

Tabel 1 Klasifikasi Penentuan Daerah Rawan Kecelakaan

\begin{tabular}{cll}
\hline No & \multicolumn{1}{c}{$Z$-Score } & \multicolumn{1}{c}{ Kriteria } \\
\hline 1. & Nilai $+(>0)$ & Rawan Kecelakaan \\
2. & Nilai $-(<0)$ & Tidak Rawan Kecelakaan \\
\hline
\end{tabular}

Menentukan interval kelas rawan kecelakaan dari nilai Z-Score, adalah:

$$
\begin{aligned}
\mathrm{I}= & \frac{Z \text { tertinggi-Z terendah }}{\sum I} \\
\text { Keterangan : } & \\
\mathrm{I} \quad= & \text { Interval } \\
\mathrm{Z} & =\text { Nilai Z-Score }
\end{aligned}
$$

\section{2) Cusum (Cumulative Summary)}

Cusum merupakan prosedur untuk mengidentifikasikan blackspot. Grafik cusum merupakan prosedur statistik standar untuk mengontrol kualitas dalam mendeteksi perubahan dari nilai rerata. Nilai cusum dihitung dengan (Austroads road engineering guides 2009, 2009):

$$
\begin{array}{rll} 
& \mathrm{W}=\frac{\sum X i}{L . T} \\
\text { Keterangan: } & \\
\mathrm{W} & =\text { Rerata } \\
\sum \mathrm{X}_{\mathrm{i}}= & \text { Jumlah kecelakaan } \\
\mathrm{L} & =\text { Jumlah stasioning } \\
\mathrm{T} & =\text { Waktu atau periode }
\end{array}
$$

Nilai cusum kecelakaan tahun pertama $\left(\mathrm{S}_{0}\right)$, adalah:

$$
\begin{aligned}
& \mathrm{S}_{0}=\left(\mathrm{X}_{1}-\mathrm{W}\right) \\
\text { Keterangan: } & \\
\mathrm{S}_{0}= & \text { Cusum kecelakaan untuk tahun pertama } \\
\mathrm{X}_{1}= & \text { Jumlah kecelakaan tiap tahun } \\
\mathrm{W}= & \text { Mean }
\end{aligned}
$$

Sedangkan nilai cusum kecelakaan tahun selanjutnya, adalah:

$$
\begin{aligned}
\text { Keterangan: } & \\
\mathrm{S} & =\text { Cusum kecelakaan } \\
\mathrm{S}_{0} & =\text { Cusum kecelakaan untuk tahun pertama } \\
\mathrm{X}_{1} & =\text { Jumlah kecelakaan tiap tahun } \\
\mathrm{W} & =\text { Rerata }
\end{aligned}
$$

Tabel 2 memperlihatkan klasifikasi penentuan titik rawan kecelakaan (blackspot).

Tabel 2 Klasifikasi Penentuan Titik Rawan Kecelakaan

\begin{tabular}{lll}
\hline No & \multicolumn{1}{c}{ Z-Score } & \multicolumn{1}{c}{ Kriteria } \\
\hline 1. & Bernilai $+(>0)$ & Rawan Kecelakaan \\
2. & Bernilai $-(<0)$ & Tidak Rawan Kecelakaan \\
\hline
\end{tabular}

$$
\begin{aligned}
& \text { Interval kelas rawan kecelakaan adalah: } \\
& \qquad \mathrm{I}=\frac{\text { Ctertinggi }- \text { C terendah }}{\Sigma^{I}} \\
& \text { Keterangan: } \\
& \begin{array}{cl}
\mathrm{I} \quad & \text { Interval } \\
\mathrm{C} \quad= & \text { Nilai cusum }
\end{array}
\end{aligned}
$$

\section{METODOLOGI}

Penelitian ini bertempat di Jalan Kartanegara, Kecamatan Karangploso, Kabupaten Malang. Kecamatan Karangploso terletak dalam wilayah Kabupaten Malang, yang terdiri dari sembilan desa. Kesembilan desa tersebut, meliputi: Tegalgondo, Tawangargo, Ngijo, Ngenep, Kepuharjo, Girimoyo, Donowarih, Bocek, dan Ampeldento. Dalam penelitian ini diambil $1 \mathrm{~km}$ yang dibagi dalam dua segmen jalan, dimana masing-masing sekmen dibagi dalam $500 \mathrm{~m}$ dengan tujuan agar mempermudah proses pengambilan data serta mempermudah analisis data nantinya. Secara administratif, Kecamatan Karangploso dikelilingi oleh kecamatan lainnya yang ada di Kabupaten Malang. 


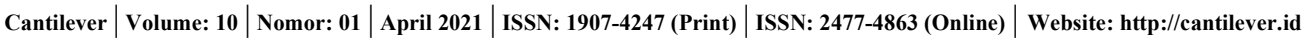

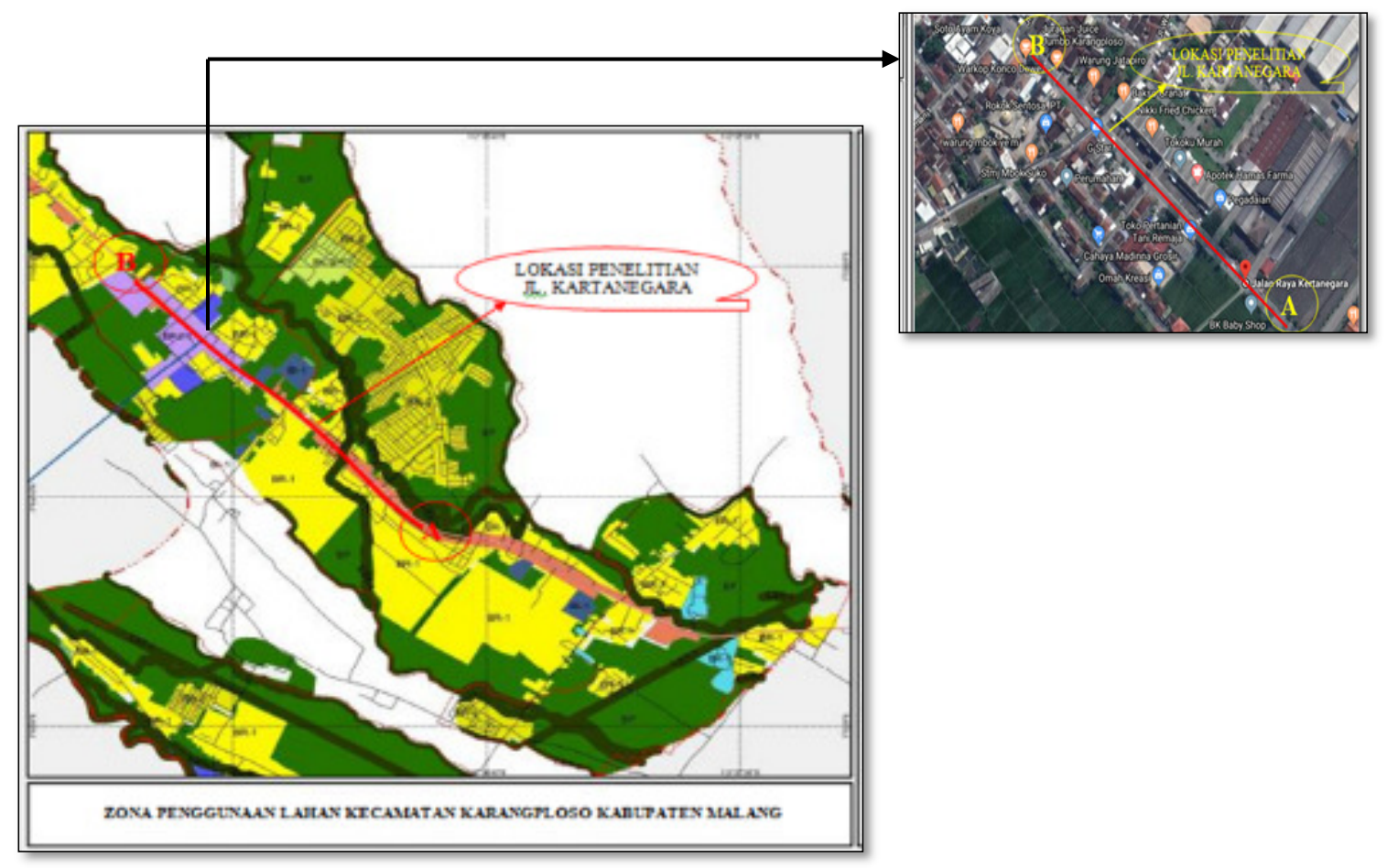

Gambar 1. Lokasi penelitian
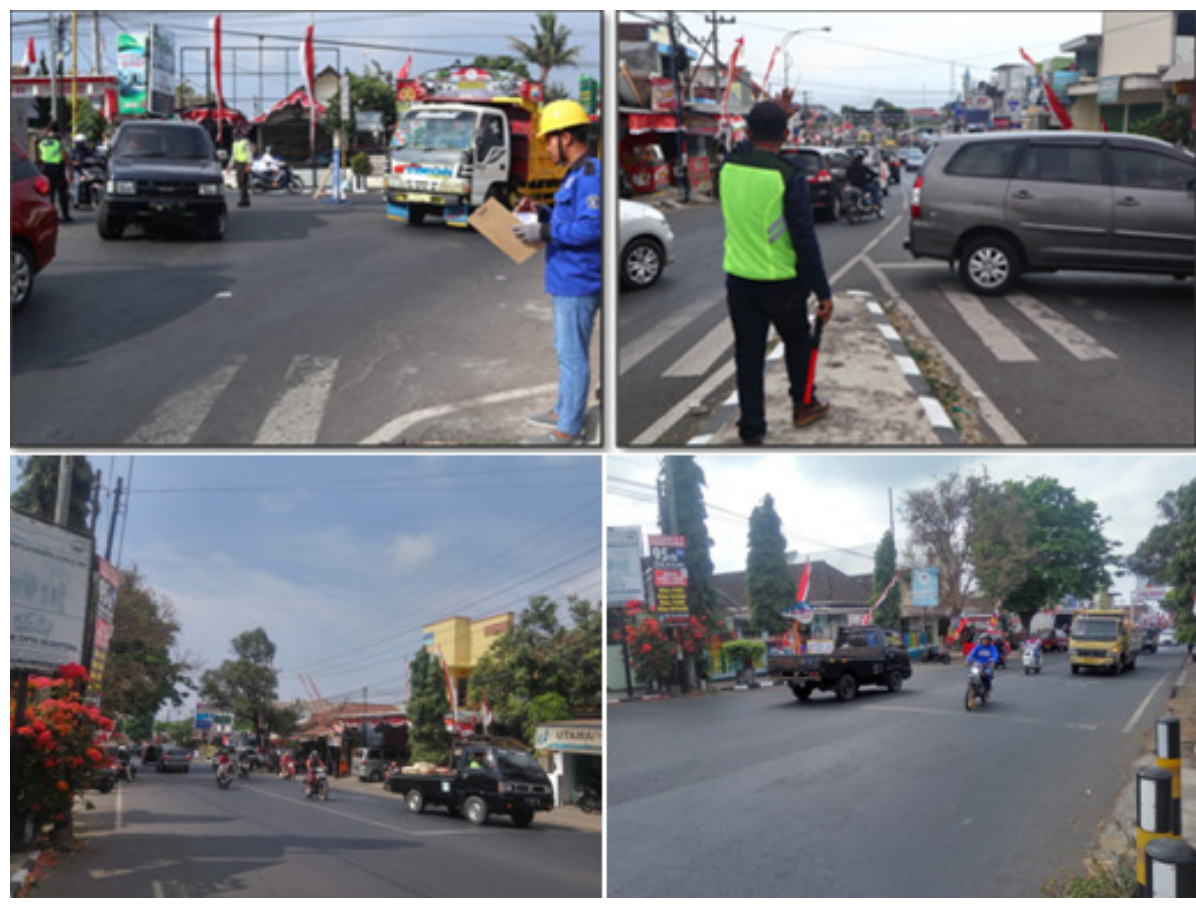

Gambar 2. Kondisi eksisting di Jalan Kertanegara

Penelitian ini menggunakan jenis penelitian kuantitatif sehingga penelitian ini dapat menganalisa maupun mengevaluasi suatu kejadian. Penelitian ini merupakan sebuah cara yang berguna mendeskripsikan atau menggambarkan hasil penelitian tetapi tidak untuk memperluas hasil kesimpulan serta menjelaskan dan memberikan informasi mengenai frekuensi kecelakaan, mengetahui lokasi titik rawan kecelakaan dan menjelaskan upaya penanganan untuk mengurangi jumlah kecelakaan (Sugiyono, 2007). Bagan alir penelitian tersaji dalam Gambar 3. 


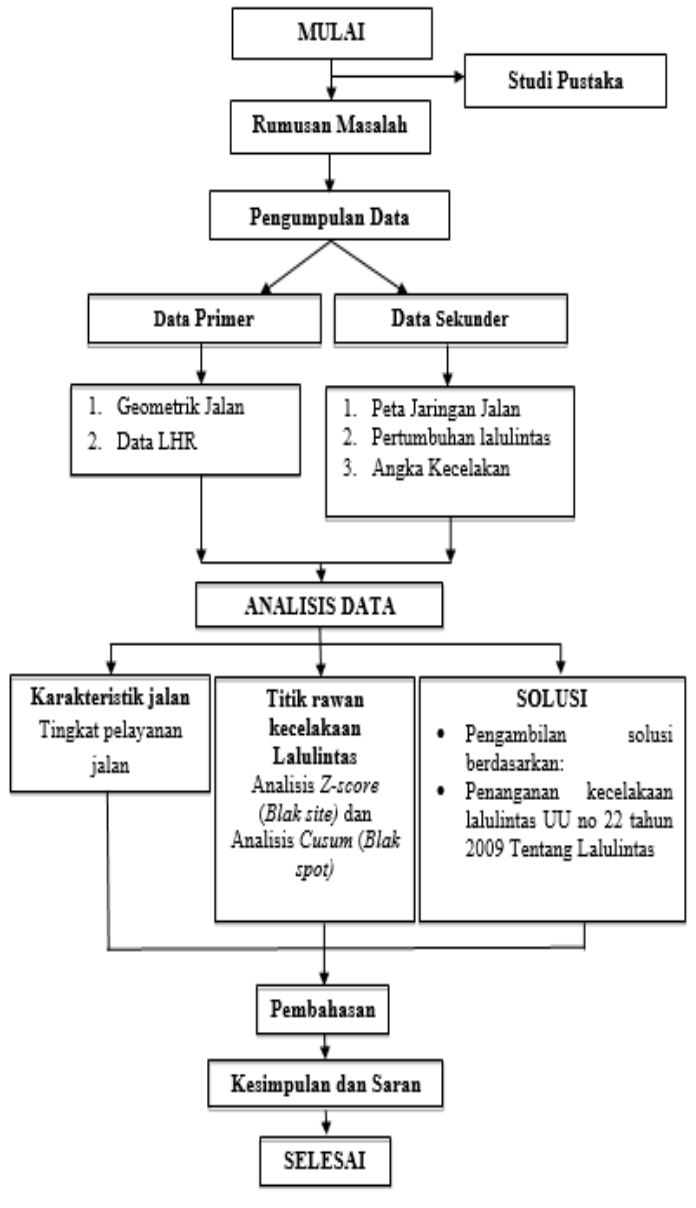

Gambar 3. Bagan Alir Penelitian

\section{HASIL DAN PEMBAHASAN}

\section{Karakteristik Jalan Kertanegara}

Jalan Kartanegara merupakan kawasan komersial, dengan banyaknya pertokoan, kios, perumahan dan pemukiman, dan perusahaan, sesuai dengan peruntukan lahannya (Peraturan Daerah Kabupaten Malang Nomor 3 Tahun 2010 tentang Rencana Tata Ruang Wilayah Kabupaten Malang, 2010). Sehingga, pada jalan ini sering terjadi masalah transportasi, salah satunya kecelakaan lalu lintas.

Penggunaan lahan timbul akibat kebutuhan dari aktivitas kehidupan manusia (Warpani, 2002),berupa: tempat tinggal, transportasi, mata pencaharian, dll. Sebagai contoh, daerah perkotaaan banyak dibangun permukiman, perkantoran, dan industri. Penggunaan lahan di sepanjang ruas jalan Kertanegara adalah guna lahan perdagangan (Gambar 4).

Tabel 3. Kondisi Eksisting Ruas Jalan Kartanegara

\begin{tabular}{ll}
\hline \multicolumn{1}{c}{ Segmen I } & \multicolumn{1}{c}{ Segmen II } \\
\hline $\begin{array}{l}\text { Kurangnya rambu lalu lintas } \\
\text { dan marka jalan di simpang }\end{array}$ & $\begin{array}{l}\text { Belum tersedianya rambu } \\
\text { lalu lintas dan marka jalan }\end{array}$ \\
jalan Polsek Karangploso dan & di simpang jalan Polsek \\
simpang jalan Sentana & $\begin{array}{l}\text { Karangploso dan simpang } \\
\text { jalan Sentana }\end{array}$ \\
Belum adanya petugas & $\begin{array}{l}\text { Belum adanya petugas } \\
\text { pengelola arus lalulintas di }\end{array}$ \\
$\begin{array}{l}\text { pengelola arus lalulintas di } \\
\text { Belum tersedianya tanda- }\end{array}$ & $\begin{array}{l}\text { Belum tersedianya tanda- } \\
\text { tanda peringatan rawan } \\
\text { kecelakaan maupun batas }\end{array}$ tanda peringatan rawan \\
kecepatan kendaraan di & kecepatan man man bendaraan di \\
simpang jalan Kauman I dan & simpang jalan Kauman I \\
simpang jalan Nuril & dan simpang jalan Nuril \\
\hline
\end{tabular}

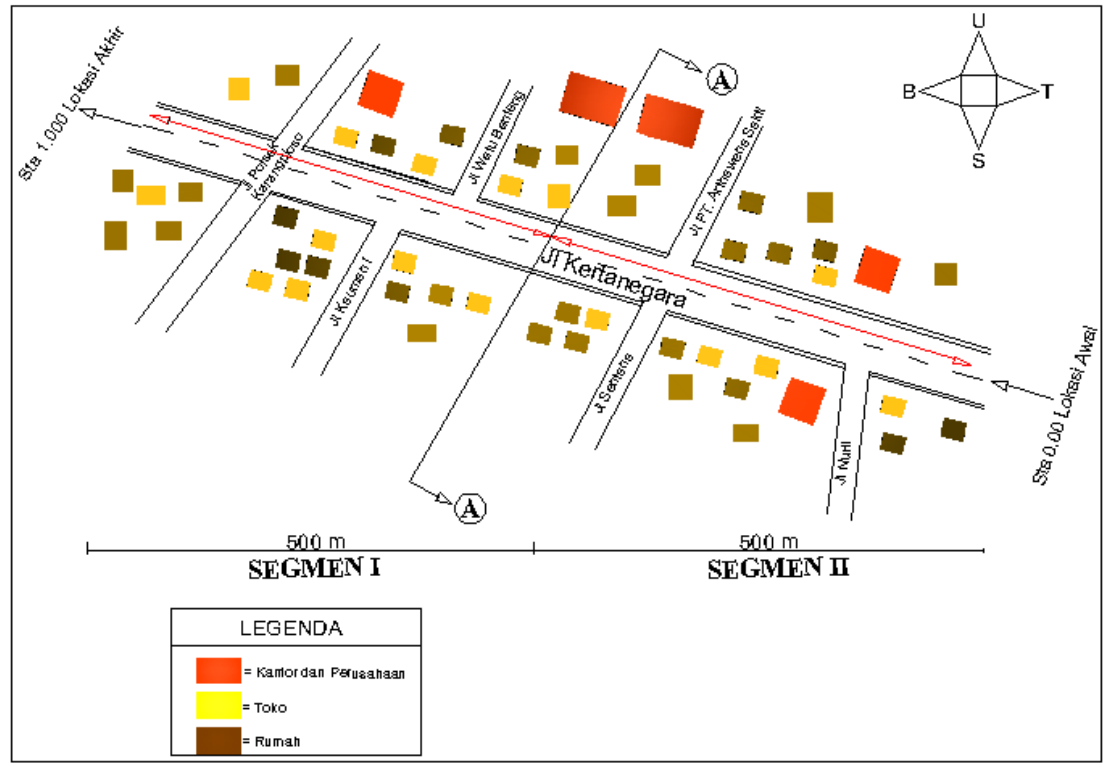

Gambar 4. Kondisi Jalan Kertanegara 


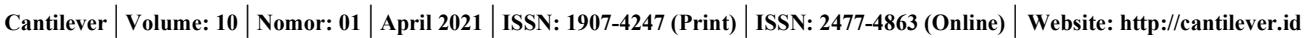
Rifky Aldila Primasworo \& Andy Kristafi Arifianto | Analisis Titik Rawan Kecelakaan di Jalan Kertanegara Kabupaten Malang

Tabel 4. Kondisi Jalan Eksisting

\begin{tabular}{ccccc}
\hline Ruas jalan & $\begin{array}{c}\text { Kondisi } \\
\text { lingkungan }\end{array}$ & $\begin{array}{c}\text { Median } \\
\text { jalan }(\mathrm{m})\end{array}$ & $\begin{array}{c}\text { Lebar } \\
\text { Jalan }(\mathrm{m})\end{array}$ & $\begin{array}{c}\text { Lebar } \\
\text { Bahu (m) }\end{array}$ \\
\hline Karangploso - Batu & Komersial & - & 9,00 & 1,00 \\
Batu - Karangploso & Komersial & & 9,00 & 1,00 \\
\hline
\end{tabular}

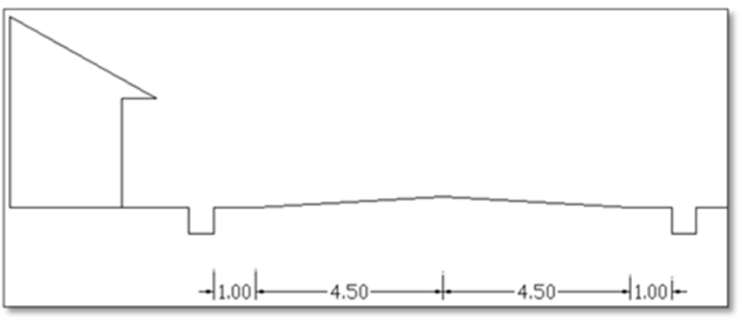

Gambar 5. Potongan melintang Jl. Kartanegara

Diperoleh jumlah arus lalu lintas total (Qtot) sebesar $1961 \mathrm{smp} / \mathrm{jam}$, serta nilai kapasitas (C) sebesar $3205 \mathrm{smp} / \mathrm{jam}$. Maka, derajat kejenuhan pada ruas jalan Kartanegara dapat dihitung menggunakan formula berdasarkan dari pedoman MKJI 1997, sebagai berikut:

$$
\begin{aligned}
D S & =\frac{\text { Qtotal }}{c} \\
D S & =\frac{1961}{3205} \\
& =0,61
\end{aligned}
$$

Dari hasil analisa kondisi eksisiting pada ruas jalan Kartanegara, diketahui nilai derajat kejenuhan adalah 0,61 $(<1,00$ sesuai ketetapan MKJI), dimana arus stabil, pengemudi memiliki keterbatasan untuk memilih kecepatan, pindah jalur atau mendahului.

\section{Analisa Titik Rawan Kecelakaan}

Karakteristik area rawan kecelakaan (lalu lintas) di jalan Kartanegara Kabupaten Malang dipengaruhi oleh total kecelakaan yang menyertakan manusia dan kendaraan. Selain itu, dipengaruhi oleh kondisi jalan, volume kendaraan, kapasitas jalan, kemiringan medan jalan, dan geometrik jalan (lebar dan panjang jalan), serta kecelakaan yang sering terjadi.

Dari data tersebut digunakan sebagai gambaran kecenderungan kecelakaan yang terjadi di ruas jalan Kartanegara Kabupaten Malang. Total kejadian kecelakaan merupakan parameter penentu dalam identifikasi daerah dan titik rawan kecelakaan.

\section{a) Rambu Lalu Lintas}

Dari survei lapangan, diketahui bahwa minimnya ketaatan terhadap peraturan lalu lintas, rambu larangan dan marka jalan, membuat kecelakaan sering terjadi di ruas jalan Kartanegara.

b) Kapasitas Jalan

Kinerja lalu lintas dinilai menggunakan Manual Kapasitas Jalan Indonesia 1996. Kapasitas merupakan arus lalu lintas maksimum yang dapat didukung pada ruas jalan / simpang pada kondisi tertentu. Kapasitas ruas jalan Kartanegara Kabupaten Malang sebesar 3.222 SMP/jam.

c) Volume Kendaraan

Volume kendaraan di jalan ini, yang terdiri dari moda transportasi: tronton, truk berat, truk sedang, bus berat, bus sedang, sedan, dan sepeda motor adalah $1.961 \mathrm{SMP} / \mathrm{jam}$.

\section{Perhitungan Z-Score untuk Identifikasi Titik Rawan Kecelakaan}

Untuk menentukan titik rawan kecelakaan (black spot) digunakan rumus Z-score. Perhitungan Z-score untuk titik rawan kecelakaan dari tahun 2016 sampai dengan tahun 2018 untuk masing-masing segmen, sbb:

\section{1) Segmen I}

a. Nilai Rerata

$$
\bar{X}=\frac{\sum X}{n}=\frac{8+3+7}{3}=6
$$

Nilai rata-rata adalah total kecelakaan tahun 2016 s.d 2018, dibagi dengan jumlah data.

b. Nilai Standar Deviasi.

$$
\mathrm{S}=\sqrt{\frac{\sum(X-\bar{X})^{2}}{n}}=\sqrt{\frac{(18-6)^{2}}{3}}=48
$$

Standar deviasi (S) merupakan akar dari jumlah kuadrat dari rerata angka kecelakaan tahun 2016 sampai dengan tahun 2018, dikurangi rata-rata angka kecelakaan, dibagi dengan jumlah data $(=3)$.

c. Nilai $Z_{i}$

$$
Z_{i}=\frac{x_{i}-\bar{X}}{s}=\frac{18-6}{48}=0,25
$$

Nilai Z-score $\left(Z_{i}\right)$ adalah rerata angka kecelakaan per tahun dikurangi rerata angka kecelakaan, dibagi simpangan baku. Ruas jalan Kartanegara memiliki nilai rata-rata jumlah angka kecelakaan sebesar 18, nilai rata-rata kecelakaan sebesar 6 , dan nilai standar deviasi sebesar 48.

\section{2) Segmen II}

$$
\text { a. Nilai Rerata } \frac{\sum X}{X}=\frac{11+6+9}{n}=8,7
$$


b. Nilai Standar Deviasi.

$$
\mathrm{S}=\sqrt{\frac{\Sigma(x-\bar{X})^{2}}{n}}=\sqrt{\frac{(26-8,7)^{2}}{3}}=99,8
$$

c. Nilai $Z_{i}$

$$
Z_{i}=\frac{X_{i}-\bar{z}}{s}=\frac{26-8,7}{99,8}=0,17
$$

\section{Perhitungan Cusum untuk Identifikasi Daerah Rawan Kecelakaan}

Black site ditentukan dengan metode Cusum, yang dapat mendeteksi perubahan kecil dari rerata. Perhitungan Cusum berdasarkan data kecelakaan tahun 2016 s.d 2018, adalah:

\section{1) Segmen $I$}

a. Nilai Rerata (W), yaitu total kecelakaan, dibagi jumlah stasioning segmen dan periode.

$$
\mathrm{W}=\frac{\sum x_{1}}{\sum x T}=\frac{18}{2 \times 3}=4,5
$$

b. Nilai cusum Kecelakaan Tahun pertama $\left(\mathrm{S}_{0}\right)$, dihitung dengan mengurangi jumlah kecelakaan dengan rerata.

$$
\mathrm{S}_{0} \quad=\left(\mathrm{X}_{1}-\mathrm{W}\right)=8-4,5=3,5
$$

c. Nilai Cusum Kecelakaan Tahun Selanjutnya $\left(\mathrm{S}_{1}\right)$, merupakan cusum kecelakaan tahun pertama ditambah total kecelakaan yang dikurangi rerata.

$$
\begin{aligned}
\mathrm{S}_{1} & =\mathrm{S}_{0}+\left(\mathrm{X}_{1}-\mathrm{W}\right) \\
& =3,5+(8-4,5)=7,00
\end{aligned}
$$

\section{2) Segmen II}

a. Mencari Nilai Mean (W)

$$
\mathrm{W}=\frac{\Sigma X_{1}}{\Sigma x^{T}}=\frac{26}{2 \times 3}=4,3
$$

b. Nilai cusum Kecelakaan Tahun pertama $\left(\mathrm{S}_{0}\right)$

$$
\mathrm{S}_{0}=\left(\mathrm{X}_{1}-\mathrm{W}\right)=11-4,3=6,7
$$

c. Mencari Nilai Cusum Kecelakaan Tahun Selanjutnya $\mathrm{S}_{1}$

$$
\begin{aligned}
\mathrm{S}_{1} & =\mathrm{S}_{0}+\left(\mathrm{X}_{1}-\mathrm{W}\right) \\
& =6,7+(11-4,3)=13,3
\end{aligned}
$$

Berdasarkan analisa diatas, serta tabel klasifikasi penentuan titik rawan kecelakaan, diketahui bahwa ruas Jalan Kartanegara Kabupaten Malang memiliki nilai Z-Score Segmen I sebesar 0,25, Segmen II sebesar 0,17, dan termasuk dalam kriteria rawan kecelakaan, dikarenakan memiliki nilai Z-Score positif. Ruas jalan Kartanegara Kabupaten Malang juga teridentifikasi sebagai daerah rawan kecelakaan (black site) karena memiliki nilai cusum positif, yaitu nilai Cusum Segmen I sebesar 7,00 dan Segmen II sebesar 13,3, dengan kriteria rawan kecelakaan. Hasil dari analisis ini sesuai dan selaras dengan penelitian (Setiawati, D. N., Intari, D. E., \& Zailani, A. , 2019)

\section{Analisis blackspot area Ruas Jalan Kartanegara Kabupaten Malang}

Blackspot area atau lokasi rawan kecelakaan

\begin{tabular}{|c|c|}
\hline Faktor & Gambar Lokasi \\
\hline $\begin{array}{l}\text { Minimnya rambu lalu lintas dan } \\
\text { marka jalan di simpang jalan Polsek } \\
\text { Karangploso. } \\
\text { Kondisi penggunaan lahan di } \\
\text { sepanjang Jalan Raya Kertanegara } \\
\text { menyebabkan ruas jalan ini sangat } \\
\text { membutuhkan infrastruktur tambahan } \\
\text { berupa lampu lalu lintas dan marka } \\
\text { jalan. }\end{array}$ & \\
\hline $\begin{array}{l}\text { - Belum adanya tanda-tanda peringatan } \\
\text { atau rambu-rambu hati-hati atau } \\
\text { batas kecepatan kendaraan di } \\
\text { simpang jalan Kauman I dan J1 Welu } \\
\text { Benteng } \\
\text { Pada Jalan Kauman I dan Welu } \\
\text { Benteng merupakan persimpangan } \\
\text { yang banyak kendaraan keluar } \\
\text { masuk. }\end{array}$ & \\
\hline $\begin{array}{l}\text { Tidak rambu-rambu lalu lintas pada } \\
\text { Jalan Sentana dan Jalan } \\
\text { PT.Arthamawena Sakt } \\
\text { - Pergerakan membelok kendaraan } \\
\text { seringkali menyebabkan terjadi } \\
\text { kecelakaan karena kelalaian } \\
\text { pengemudi dan tidak adanya alat } \\
\text { bantu isyarat lalu lintas yang } \\
\text { memadai pada simpang tersebut. } \\
\end{array}$ & \\
\hline $\begin{array}{l}\text { - Terdapat tikungan yang tidak } \\
\text { memiliki rambu dan penerangan } \\
\text { jalan umum sehingga membahayakan } \\
\text { pengendara pada .persimpangan } \\
\text { Jalan Nuril. }\end{array}$ & \\
\hline
\end{tabular}
dapat dilihat dari: tingkat intensitas kejadian kecelakaan lalu lintas, kondisi jalan yang tidak sesuai standart layak fungsi jalan, kondisi hambatan samping di sekitar ruas jalan dengan intensitas tinggi, dan tingkat kelengkapan infrastruktur. Berdasarkan hasil survei lapangan, didapatkan kondisi ruas Jalan Kertanegara, yaitu (Tabel 5):

Tabel 5. Potensi Lokasi Rawan Kecelakaan di Ruas Jalan Kertanegara Kabupaten Malang

\section{Solusi Alternatif Mengatasi Titik Rawan Kecelakaan Di Jalan Kertanegra}

Solusi alternatif disusun berdasarkan panduan dari Direktur Jenderal Perhubungan Darat No. SK.7234/AJ.401/DRJD/2013 tentang Petunjuk Teknis Perlengkapan Jalan.

Lokasi titik rawan kecelakan yang sering terjadi yaitu pada ruas jalan Kartanegara segmen II, atau lebih tepatnya simpang jalan Nuril, karena pada simpang tersebut masih terlihat belum maksimalnya fasilitas jalan seperti rambu lalu lintas. Hal ini diperkuat dengan penjelasan beberapa anggota 
Cantilever $\mid$ Volume: 10 Nomor: 01 April $2021 \mid$ ISSN: 1907-4247 (Print) $\mid$ ISSN: 2477-4863 (Online) $\mid$ Website: http://cantilever.id Rifky Aldila Primasworo \& Andy Kristafi Arifianto | Analisis Titik Rawan Kecelakaan di Jalan Kertanegara Kabupaten Malang

Satlantas yang bertugas pada saat penelitian yang menyatakan lokasi paling sering terjadi kecelakaan pada simpang jalan Nuril dan simpang jalan Kauman I serta berdasarkan data yang diambil dari dinas
Satlantas. Angka kecelakan dibagi dalam dua segmen sehingga dalam penelitian ini angka tertinggi terjadi pada segmen II dengan angka kecelakaan tertinggi (Gambar 6).

Tabel 6. Kondisi Geometri Ruas Jalan Kertanegara Kabupaten Malang

\begin{tabular}{|c|c|c|c|c|c|c|}
\hline \multirow[t]{2}{*}{ Nama Ruas } & \multirow[t]{2}{*}{ Fungsi Jalan } & \multicolumn{4}{|c|}{ Kondisi Geometri/Fisik } & \multirow[t]{2}{*}{ Ket. } \\
\hline & & Aspek & Standart & Eksisting & Kesesuaian & \\
\hline Ruas Jalan & Kolektor & Tipe Jalan & $2 / 2 \mathrm{UD}$ & $2 / 2 \mathrm{UD}$ & Sesuai & Tidak \\
\hline Kertanegara & Sekunder & Lebar Badan Jalan & $7 \mathrm{~m}$ & $9 \mathrm{~m}$ & Sesuai & Berkeselamatan \\
\hline & & Median & Tidak Ada & Tanpa Median & Sesuai & (4 aspek tidak \\
\hline & & Bahu Jalan & $1,5 \mathrm{~m}$ & $1 \mathrm{~m}$ & Tidak Sesuai & sesuai) \\
\hline & & Trotoar & $1 \mathrm{~m}$ & Tidak Ada & Tidak Sesuai & \\
\hline & & Kondisi Saluran & $1 \mathrm{~m}$ & Tidak Ada & Tidak Sesuai & \\
\hline & & Jenis Perkerasan & $\begin{array}{l}\text { Berpenutup } \\
\text { aspal/beton }\end{array}$ & $\begin{array}{l}\text { Aspal (kondisi } \\
\text { berlubang) }\end{array}$ & Tidak Sesuai & \\
\hline
\end{tabular}

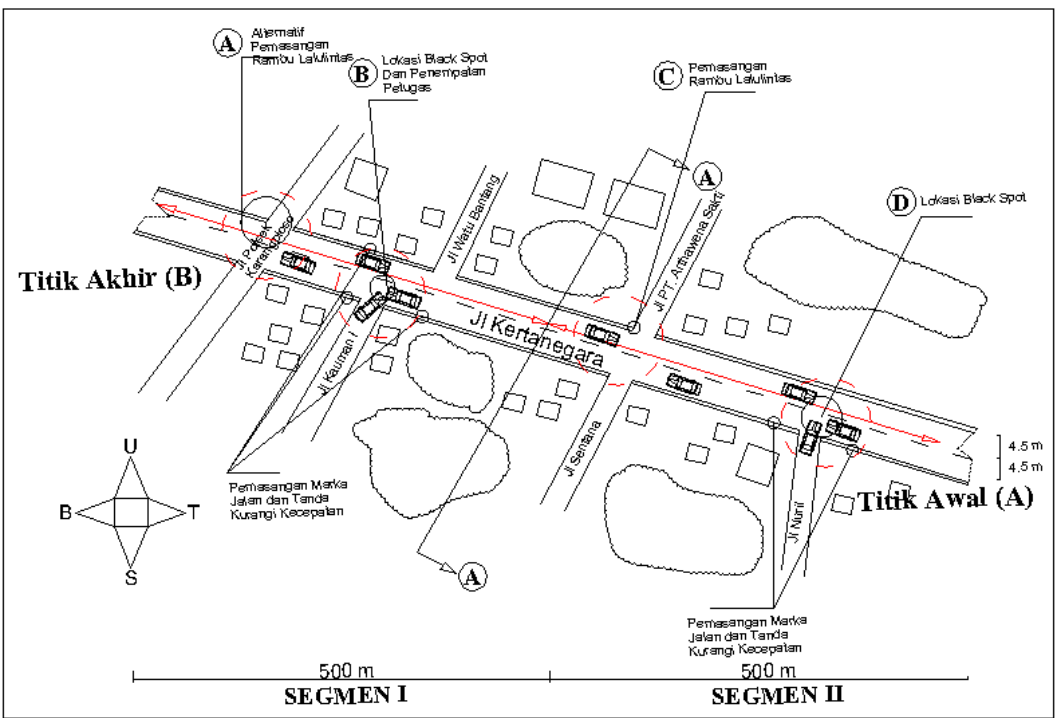

Gambar 6. Titik Lokasi Kecelakaan

Diketahui beberapa simpang jalan yang dianggap belum dan masih kurangnya rambu lalulintas pada simpang jalan Polsek Karangploso dan simpang jalan Sentana. Sedangkan pada Simpang jalan Nuril dan Kauman belum tersedianya rambu lalu lintas sesuai panduan (Peraturan Menteri Perhubungan Republik Indonesia Nomor PM 49 Tahun 2014 tentang Alat Pemberi Isyarat Lalu Lintas, 2014). Solusi yang diusulkan untuk kedua segmen jalan ini adalah (Tabel 7):

\section{Alternatif I}

Pemasangan rambu lalulintas (Peraturan Menteri Perhubungan Republik Indonesia Nomor PM 49 Tahun 2014 tentang Alat Pemberi Isyarat Lalu Lintas, 2014) dibutuhkan karena pada lokasi penelitian, para pengendara sering lepas kontrol dalam berkendara seperti halnya mengendarai dengan kecepatan tinggi sehingga dianggap masih minimnya rambu lalulintas di simpang jalan Polsek
Karangploso dan simpang jalan Sentana. Alternatif solusi dalam mengatasi titik kecelakaan lalu lintas selaras dengan penelitian (Andri, O., Widodo, S., \& Mayuni, S., 2016).

\section{Alternatif II}

Penempatan petugas dari Dinas perhubungan maupun Satlantas pada titik yang dianggap merupakan titik rawan kecelakan, seperti pada simpang jalan Nuril, sehingga pelayanan lalulintas pada simpang jalan Nuril dapat bekerja maksimal, dapat ditaati oleh para pengendara, dan dapat berkendara dengan berhati-hati.

\section{Alternatif III}

Penempatan tanda-tanda peringatan rawan kecelakaan maupun batas kecepatan kendaraan di simpang jalan Kauman I dan simpang jalan Nuril. 


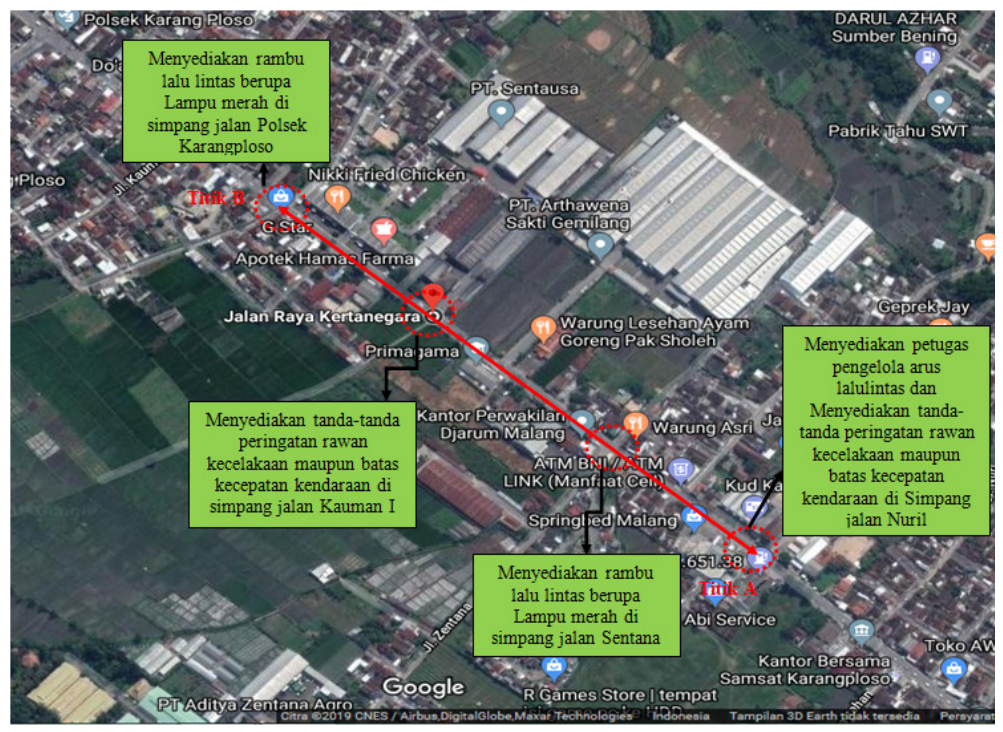

Gambar 7. Solusi Alternatif Penyelesaian Permasalahan

Tabel 7. Solusi Alternatif Titik Rawan Kecelakaan

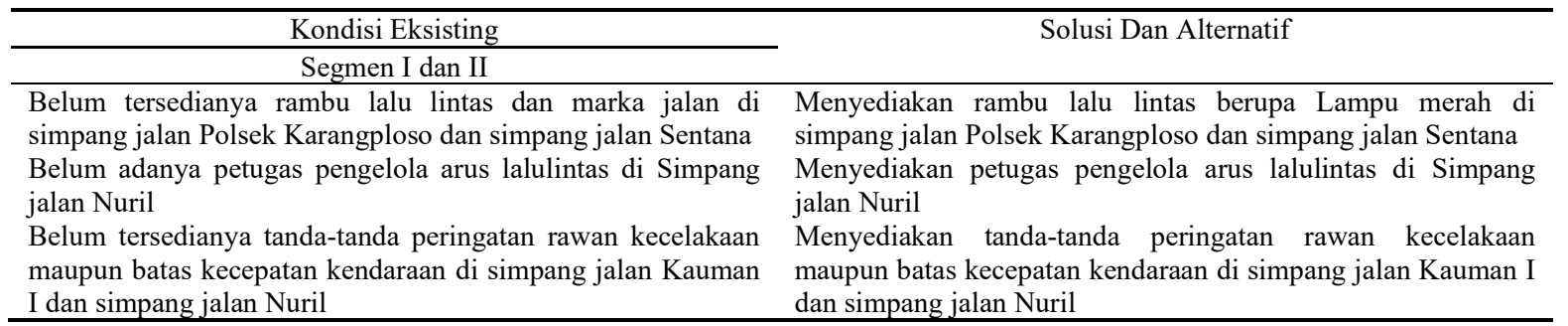

\section{KESIMPULAN}

Adapun kesimpulan yang dapat diberikan, yaitu

1) Karakteristik ruas jalan diketahui sering terjadi kecelakaan serta diketahui kondisi hambatan samping sedang, kecepatan arus bebas kendaraan yang tinggi, jumlah arus lalu lintas yang rendah serta nilai kapasitas jalan tinggi sehingga menjadikan jalan Kertanegara memiliki tingkat pelayanan $\mathrm{C}$.

2) Dari hasil analisa diketahui bahwa jalan Kartanegara teridentifikasi sebagai titik rawan kecelakaan (black spot), yaitu pada segmen II atau pada simpang jalan Nuril, karena memiliki nilai Z-Score dan cusum yang tinggi serta bernilai positif.

3) Solusi penanggulangan tingkat kecelakan diantaranya:

- Pemasangan rambu lalu lintas lampu merah dan marka jalan di simpang jalan Polsek Karangploso dan simpang jalan Sentana.

- Penempatan petugas pelayanan lalulintas di Simpang jalan Nuril

- Pemasangan tanda kurangi kecepatan dan tanda rawan kecelakaan di simpang jalan Kauman I dan simpang jalan Nuril.

\section{REFERENSI}

Andri, O., Widodo, S., \& Mayuni, S. (2016). Analisis lokasi rawan kecelakaan lalu lintas di Jalan Trans Kalimantan (Kuala Ambawang - Simpang Ampar). Jurnal Mahasiswa Teknik Sipil Universitas Tanjungpura, 3(3), 1-13.

Austroads road engineering guides 2009. (2009). Australia: The NZ Transport Agency.

Mubina, U. H., Gaus, A., Pasri, A. A., \& Damayanti, Y. (2020). Uji laik fungsi jalan dalam mewujudkan jalan yang berkeselamatan studi kasus jalan utama Kota Weda. Journal of Science and Engineering, 17-24.

Peraturan Daerah Kabupaten Malang Nomor 3 Tahun 2010 tentang Rencana Tata Ruang Wilayah Kabupaten Malang. (2010). Malang: Pemerintah Kabupaten Malang.

Peraturan Direktur Jenderal Perhubungan Darat No. SK.7234/AJ.401/DRJD/2013 tentang Petunjuk Teknis Perlengkapan Jalan. (2013). Jakarta: Direktur Jenderal Perhubungan Darat.

Peraturan Menteri Perhubungan Republik Indonesia Nomor PM 49 Tahun 2014 tentang Alat Pemberi Isyarat Lalu Lintas. (2014). Jakarta: Kementrian Perhubungan.

Peraturan Menteri Perhubungan Republik Indonesia Nomor: PM 26 Tahun 2015 Tentang Standar Keselamatan Lalu Lintas Dan Angkutan Jalan. (2015). Jakarta: Kementrian Perhubungan.

Peraturan Direktur Jenderal Perhubungan Darat Nomor: SK.2574/AJ.403/DRJD/2017. (2017). Jakarta: Direktur Jenderal Perhubungan Darat.

Setiawati, D. N., Intari, D. E., \& Zailani, A. . (2019). Analisis titik rawan kecelakaan lalu lintas pada ruas jalan provinsi 
Cantilever $\mid$ Volume: 10 Nomor: 01 April $2021 \mid$ ISSN: 1907-4247 (Print) $\mid$ ISSN: 2477-4863 (Online) $\mid$ Website: http://cantilever.id

Rifky Aldila Primasworo \& Andy Kristafi Arifianto | Analisis Titik Rawan Kecelakaan di Jalan Kertanegara Kabupaten Malang

(Studi kasus: J1. Raya Legok dan Jl. Raya Kelapa Dua Kab. Tangerang). Jurnal Kajian Teknik Sipil, 4(1) , 76-86.

Sugiyono. (2007). Metode Penelitian Kuantitatif Kualitatif dan $R \& D, 10$ th ed. Bandung: Alfabeta.

UU No. 38 tahun 2004 tentang Jalan. (2004). Jakarta: Sekretariat Negara.
UU No. 22 Tahun 2009 tentang Lalu Lintas dan Angkutan Jalan. (2009). Jakarta: Kementerian Perhubungan.

Warpani, S. P. (2002). Pengelolaan Lalu Lintas dan Angkutan Jalan, 2nd ed. Bandung: Penerbit ITB. 